\title{
A carbon nanotube-reinforced noble tin anode structure for lithium-ion batteries
}

\author{
Susumu Arai ${ }^{1} \cdot$ Ryosuke Fukuoka $^{1}$
}

Received: 30 September 2015/ Accepted: 16 January 2016/Published online: 25 January 2016

(c) The Author(s) 2016. This article is published with open access at Springerlink.com

\begin{abstract}
A carbon nanotube (CNT)-reinforced noble tin anode structure in which CNTs fasten the tin layer to a copper underlayer has been fabricated using plating techniques so as to improve the cyclability of lithium-ion batteries. In this process, a Cu/CNTs composite layer, on one side of which CNTs protrude from the surface, is formed using a reverse current electrodeposition technique. The surface of this composite layer is subsequently coated with a tin layer by a substitution-type electroless plating technique, resulting in the CNT-reinforced noble tin anode
\end{abstract}

structure. The electrochemical characteristics of this noble tin anode structure have been evaluated and compared to those of a tin anode structure without CNTs. The noble tin anode structure shows significantly improved cyclability compared with the tin anode structure and maintains a higher reversible capacity of $591 \mathrm{mAh} \mathrm{g}^{-1}$, a value that is 1.6 times the theoretical capacity of graphite, even after 30 cycles.

\section{Graphical Abstract}
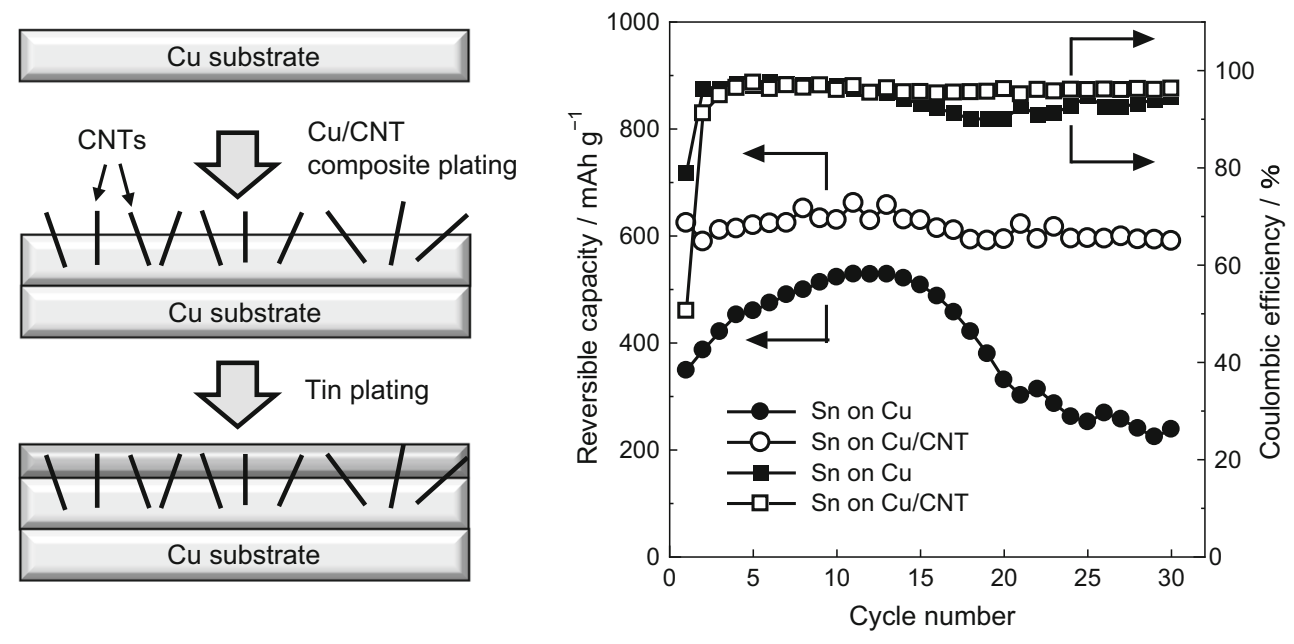

Susumu Arai

araisun@shinshu-u.ac.jp

1 Department of Chemistry and Material Engineering, Faculty of Engineering, Shinshu University, 4-17-1 Wakasato, Nagano 380-8553, Japan
Keywords Lithium-ion battery - Tin anode - Carbon nanotube $\cdot$ Plating $\cdot$ Cyclability 


\section{Introduction}

Lithium-ion batteries have the highest energy density values among practical battery systems and thus have been widely used as power sources for portable devices and hybrid cars. However, next-generation electric vehicles demand higher performance than is provided by conventional lithium-ion batteries. Presently, graphite is the most common anode material for lithium-ion batteries due to its low cost, availability, and durability, but the practical capacity of graphite has a theoretical limit of $372 \mathrm{mAh} \mathrm{g}^{-1}$. Consequently, alternative anode materials with higher capacities have been researched vigorously. Tin in particular has a theoretical capacity of $994 \mathrm{mAh} \mathrm{g}^{-1}$ and therefore has been investigated as one of the most promising prospective next-generation anode materials [1]. Since tin layers can be formed on copper current collectors by plating, the research and development of electrodeposited tin materials have been the main focus. As opposed to graphite anodes that react with $\mathrm{Li}^{+}$ions by intercalation, tin anodes react with $\mathrm{Li}^{+}$ions by alloying. The alloying and dealloying reactions result in a considerable volume change and eventual pulverization of the active tin material, leading to isolation of the tin from the copper current collector during charge-discharge cycling, thus producing poor cyclability. To overcome this problem, the following strategies have all been investigated: the formation of an intermetallic layer between the tin and copper layers by annealing [2]; the modification of the tin grain size by pulse electrodeposition [3]; the use of tin electrodeposition to form a multi-layered structure [4]; Sn-based electrodeposited alloy materials such as $\mathrm{Sn}-\mathrm{Cu}$ [5-7], $\mathrm{Sn}-\mathrm{Ni}$ [8-10], $\mathrm{Sn}-\mathrm{Sb}[1,11]$, and $\mathrm{Sn}-\mathrm{Ag}$ [1]; a $\mathrm{Sn}-\mathrm{Ni}$ alloy three-dimensional structure formed using electrodeposition [12]; tin and tin-based electrodeposits on three dimensional copper current collectors [13, 14]; an electrodeposited tin film reinforced with copper nanowires [15]; and electrodeposited tin films on carbon fibers [16]. However, further improvements of both the practical specific capacity and the cyclability of tin-based anodes, as well as the development of practical fabrication processes, are still required.

Since carbon nanotubes (CNTs) $[17,18]$ have superior mechanical properties, good electro-conductivity, and low density, CNT-reinforced tin anodes are expected to show improvements in anode performance characteristics, especially cyclability. $\mathrm{Li}$ et al. have reported that a $\mathrm{Sn} / \mathrm{CNTs}$ composite film formed by electrodeposition exhibits improved first charge and discharge capacities compared with a tin film, although the capacity decreases with increasing cycle number [19]. Zhao et al. have reported that a $\mathrm{Sn} / \mathrm{CNTs}$ composite film shows poor cyclability that is almost the same as that of pure tin [20]. In order to enhance the cyclability of tin active material layers, an anode structure in which the adhesion strength between the tin layer and the copper layer are reinforced by fibrous objects such as the CNTs may potentially be effective. We have therefore studied the fabrication of various metal/CNTs composite films, such as $\mathrm{Cu} / \mathrm{CNTs}$ [21-25], using plating techniques. In the present study, a CNT-reinforced noble tin anode structure in which the CNTs fasten the tin active material layer and the copper underlayer was produced using a plating technique, and the electrochemical characteristics of the resulting noble anode were evaluated.

\section{Experimental}

\subsection{Fabrication of the CNT-reinforced tin anode structure}

Figure 1 summarizes the fabrication process used to make the CNT-reinforced tin anode structure. A $\mathrm{Cu} / \mathrm{CNT}$ s composite layer is initially generated on the copper substrate using an electrodeposition technique. Next, a tin layer is formed over the $\mathrm{Cu} / \mathrm{CNTs}$ composite layer, employing a plating technique, resulting in a CNT-reinforced tin anode structure in which the CNTs assist in fastening the tin layer to the copper layer.

\subsubsection{Formation of the Cu/CNTs composite layer}

The present work used commercially available, vaporgrown, multi-walled CNTs (Showa Denko Co. Ltd., VGCF-H) formed via catalyst-assisted chemical vapor

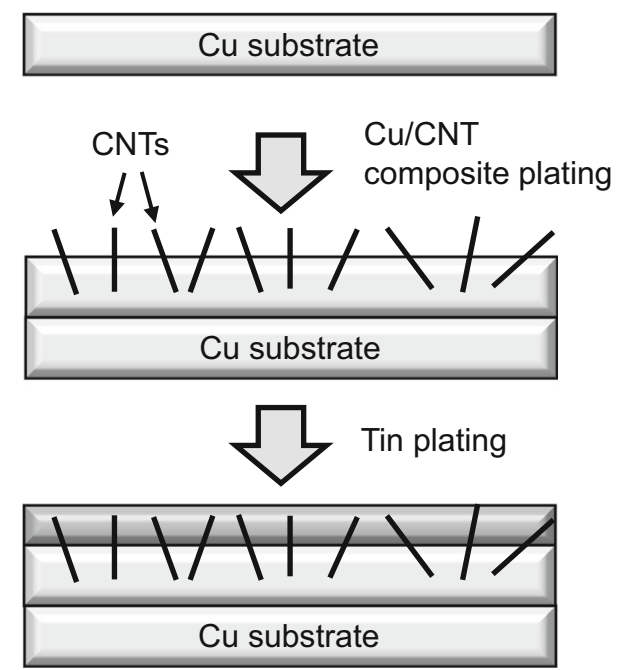

Fig. 1 Fabrication process used to generate the new tin anode structure 
deposition (CVD) and heat treated at $2800{ }^{\circ} \mathrm{C}$ in an argon gas atmosphere for $30 \mathrm{~min}$. These CNTs were typically 100 $200 \mathrm{~nm}$ in diameter and $10 \mu \mathrm{m}$ in length. The $\mathrm{CuSO}_{4}$ $5 \mathrm{H}_{2} \mathrm{O}, \mathrm{H}_{2} \mathrm{SO}_{4}$, and polyacrylic acid (PA-5000, mean molecular weight of 5000) employed in this study were all reagent grade. A $0.85 \mathrm{M} \mathrm{CuSO}_{4} \cdot 5 \mathrm{H}_{2} \mathrm{O} / 0.55 \mathrm{M} \mathrm{H}_{2} \mathrm{SO}_{4} /$ $2 \times 10^{-5} \mathrm{M}$ PA-5000/2 $\mathrm{g} \mathrm{dm}^{-3} \mathrm{CNT}$ solution was used as the $\mathrm{Cu} / \mathrm{CNT}$ composite plating bath, while a $0.85 \mathrm{M}$ $\mathrm{CuSO}_{4} \cdot 5 \mathrm{H}_{2} \mathrm{O} / 0.55 \mathrm{M} \mathrm{H}_{2} \mathrm{SO}_{4}$ solution was prepared as the copper plating bath. Pure copper plate $(300 \mu \mathrm{m}$, Yamamoto-Ms Co., Ltd.) with an exposed surface area of $10 \mathrm{~cm}^{2}$ was employed as the substrate, while a copper plate containing phosphorus served as the anode. A reverse current electrodeposition technique [26] was employed to form a $\mathrm{Cu} / \mathrm{CNTs}$ composite layer containing numerous CNTs. These $\mathrm{Cu} / \mathrm{CNT}$ s composite films were fabricated from the $\mathrm{Cu} / \mathrm{CNTs}$ composite plating bath using an electrochemical measurement system (Hokuto Denko Co., HZ-5000) while agitating the bath with air bubbles at $25{ }^{\circ} \mathrm{C}$. Figure 2 shows the waveform applied during the reverse current electrodeposition. A cathodic current was applied as the $\mathrm{Cu}$ / CNTs composite film was electrodeposited, while an anodic current was applied to dissolve a portion of the copper matrix of the deposited $\mathrm{Cu} / \mathrm{CNT}$ s composite film, resulting in increased protrusion of the CNTs on the $\mathrm{Cu} / \mathrm{CNTs}$ composite film surface. As the cathodic and anodic current cycles are repeated, the amount of CNTs in and on the composite film increases. The cathode current density was set to $1 \mathrm{~A} \mathrm{dm}^{-2}$ and the cathodic deposition time was $3000 \mathrm{~s}$, and these values generated a mean $\mathrm{Cu} / \mathrm{CNTs}$ composite film thickness of approximately $10 \mu \mathrm{m}$. The anodic current density was set to $5 \mathrm{~A} \mathrm{dm}^{-2}$ and the anodic dissolution time was $300 \mathrm{~s}$, corresponding to a mean copper matrix layer dissolution thickness of approximately $5 \mu \mathrm{m}$. One waveform cycle, consisting of a single cathodic deposition and a single anodic dissolution, resulted in an approximately 5 - $\mu$ m-thick $\mathrm{Cu} / \mathrm{CNTs}$ composite layer. In this study, the $\mathrm{Cu} / \mathrm{CNT}$ s composite layer was fabricated by

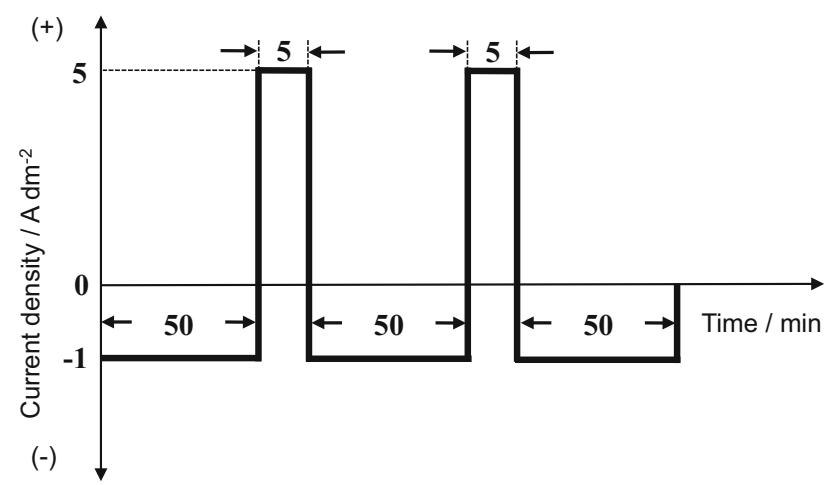

Fig. 2 Waveform for RC electrodeposition of the $\mathrm{Cu} / \mathrm{MWCNTs}$ composite film applying two wave cycles plus one additional cathodic deposition, resulting in a $\mathrm{Cu} / \mathrm{CNT}$ s composite film thickness on the order of $20 \mu \mathrm{m}$, containing numerous CNTs. Although the reproducibility of the $\mathrm{Cu} / \mathrm{CNT}$ s composite films was reasonable, the quantity of CNTs on or in the films varied to some degree. For comparison purposes, an approximately 20 - $\mu$ m-thick copper layer was also electrodeposited using direct current electrodeposition from the copper plating bath.

\subsubsection{Formation of the tin layer}

The tin layer was fabricated by electroless plating, using $\mathrm{Sn}_{2} \mathrm{P}_{2} \mathrm{O}_{7}, \mathrm{~K}_{4} \mathrm{P}_{2} \mathrm{O}_{7}, \mathrm{CS}\left(\mathrm{NH}_{2}\right)_{2}$, and $\mathrm{HCl}$, all of which were reagent grade. A replacement-type electroless deposition method was employed in this study to form tin layers both on the $\mathrm{Cu} / \mathrm{CNT}$ s composite layer and on the copper layer. A $0.1 \mathrm{M} \mathrm{Sn}{ }_{2} \mathrm{P}_{2} \mathrm{O}_{7} / 0.4 \mathrm{M} \mathrm{K}_{4} \mathrm{P}_{2} \mathrm{O}_{7} / 8 \mathrm{M} \mathrm{CS}\left(\mathrm{NH}_{2}\right)_{2}$ solution was used as the replacement-type tin electroless deposition bath, the $\mathrm{pH}$ of which was adjusted to 5 by the addition of $\mathrm{HCl}$. The electroless deposition of tin was performed at $90{ }^{\circ} \mathrm{C}$ over $600 \mathrm{~s}$ to produce a tin film with a thickness of about $1 \mu \mathrm{m}$. The amount of tin deposited per unit surface area was determined using X-ray fluorescence spectroscopy (XRF, Rigaku ZSX Primus II).

\subsection{Characterization of the anode structure}

The morphology of each electrodeposited specimen was observed using field emission scanning electron microscopy (FE-SEM, Hitachi Co., Ltd., SU8000). The phase structures of the samples were evaluated by X-ray diffraction (XRD, Shimadzu Seisakusho XRD-6000) with $\mathrm{Cu} \mathrm{K} \alpha_{1}$ radiation.

\subsection{Electrochemical measurements}

The electrochemical properties of samples were assessed using CR2032-type coin cells. A three-electrode cell configuration, consisting of a fabricated tin electrode (working electrode, WE), Li foil [reference electrode (RE), and counter electrode $(\mathrm{CE})]$, and a $1.0 \mathrm{M}$ solution of $\mathrm{LiPF}_{6}$ in a mixed solvent (ethylene carbonate: diethyl carbonate $=1: 1$ by volume), was employed. The coin cells were assembled in an argon-filled glove-box. Cyclic voltammetry (CV) was carried out using a computer-controlled electrochemical measurement system (Bio-Logic Co., VSP) and cyclic volt ammograms were acquired at a scan rate of $0.05 \mathrm{mV} \mathrm{s}^{-1}$ over the potential range of $0.02-1.5 \mathrm{~V}$ (vs. $\mathrm{Li} / \mathrm{Li}^{+}$). Charge-discharge measurements were conducted galvanostatically using an automatic charge-discharge ins trument (Hokuto Denko Co., HJ1001SD8) at a current density of $100 \mathrm{~mA} \mathrm{~g}^{-1}$ (a rate of approximately $0.1 \mathrm{C}$ ) 

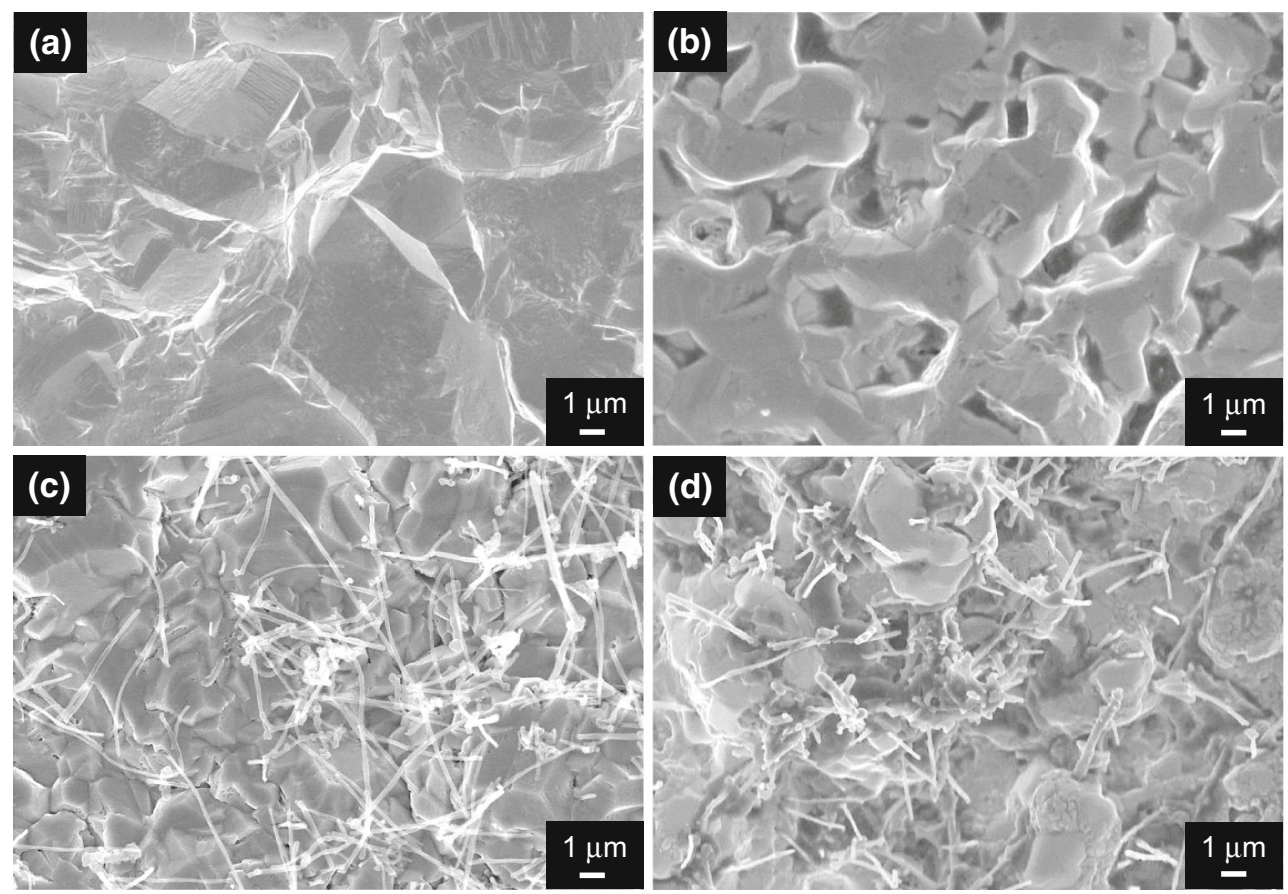

Fig. 3 Surface SEM images of a an electrodeposited copper film prior to electroless tin plating, $\mathbf{b}$ an electrodeposited copper film following electroless tin plating, $\mathbf{c}$ an electrodeposited $\mathrm{Cu} / \mathrm{MWCNTs}$

between 0.02 and $1.2 \mathrm{~V}$ (vs. $\mathrm{Li} / \mathrm{Li}^{+}$). All electrochemical measurements were performed at room temperature. The specific capacity of each sample was calculated by dividing the quantity of electricity passed through the cell by the mass of the tin.

\section{Results and discussion}

\subsection{Surface morphology of the anode structure}

Figure $3 \mathrm{a}, \mathrm{b}$ presents the surface morphologies of a copper film before and after electroless tin plating, respectively. Copper grains several $\mu \mathrm{m}$ in diameter are seen on the copper film prior to processing (Fig. 3a) while, subsequent to the tin plating, the surface roughness is somewhat increased (Fig. 3b). Figure 3c, d shows the surface morphologies of a $\mathrm{Cu} / \mathrm{CNTs}$ composite film before and after electroless tin plating, respectively. Bare CNTs are seen on the composite film surface prior to processing. That is, one end of each CNT protrudes from the surface of the composite film (Fig. 3c, see also Fig. 1). On the contrary, the copper surface is seen to be fully coated such that the CNTs are embedded within the deposited tin after plating (Fig. 3d), resulting in the CNTs-reinforced noble tin anode structure shown in Fig. 1. Since a portion of each CNT still protrudes slightly from the surface of the deposited tin composite film prior to electroless tin plating, and $\mathbf{d}$ an electrodeposited $\mathrm{Cu} / \mathrm{MWCNTs}$ composite film following electroless tin plating

- Tetragonal tin ( $\beta-S n)$ : 04-0673

๑ Monoclinic Cu6Sn5 : 45-1488

o Face-centered cubic copper : 04-0836

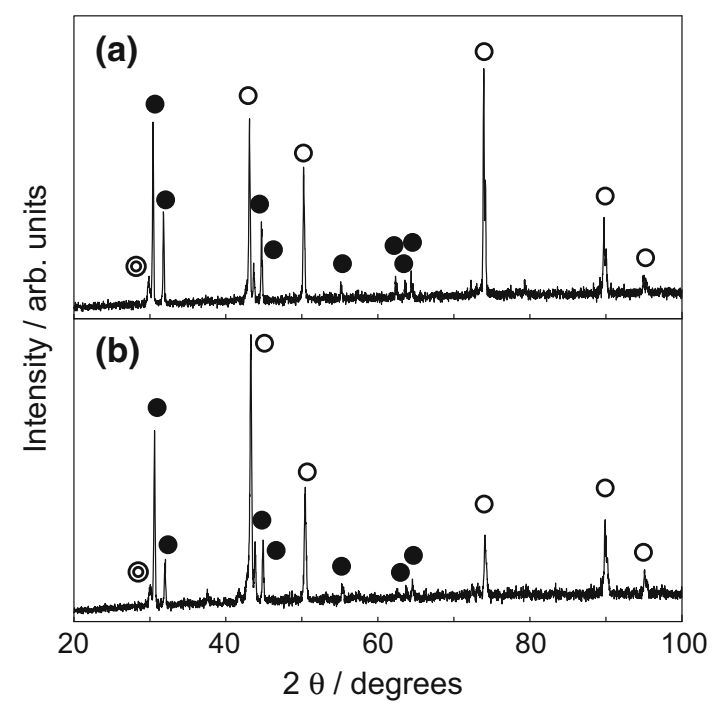

Fig. 4 XRD patterns for a an electrodeposited copper film following electroless tin plating and $\mathbf{b}$ an electrodeposited $\mathrm{Cu} / \mathrm{MWCNTs}$ composite film following electroless tin plating (equivalent to the new tin anode structure)

layer, the surface roughness is somewhat greater than that of the $\mathrm{Cu} / \mathrm{CNT}$ s composite film, just as seen with the tin layer on the copper layer (Fig. 3a, b). 
Figure $4 \mathrm{a}$ provides the XRD patterns of a tin layer on a copper layer. The diffraction peaks marked by white circles were assigned to face-centered cubic copper in the copper underlayer. All other diffraction peaks were attributed to either tetragonal tin ( $\beta$-Sn phase) or monoclinic $\mathrm{Cu}_{6} \mathrm{Sn}_{5}$. The intensity of the $\mathrm{Cu}_{6} \mathrm{Sn}_{5}$ peak is weak compared to that of the tetragonal tin peak. Figure $4 \mathrm{~b}$ shows the XRD pattern of a tin layer on a Cu/CNTs composite layer, that is, the CNTs-reinforced noble tin anode structure, and is very similar to the pattern in Fig. 4a. No diffraction peaks due to the CNTs are seen, suggesting that the quantity of CNTs was insufficient to allow XRD detection. Du et al. have reported that similar $\beta-\mathrm{Sn}$ and $\mathrm{Cu}_{6} \mathrm{Sn}_{5}$ phases are formed during replacement-type electroless tin plating on a copper layer, and have found that the formation of a $\mathrm{Cu}_{6} \mathrm{Sn}_{5}$ layer strengthens the bonding between the tin and copper layers, resulting in good cyclability [27]. In the present study, the $\mathrm{Cu}_{6} \mathrm{Sn}_{5}$ layer was also expected to equally enhance the cyclability of both the tin layer on the copper layer and the tin layer on the $\mathrm{Cu} / \mathrm{CNT}$ s composite layer.
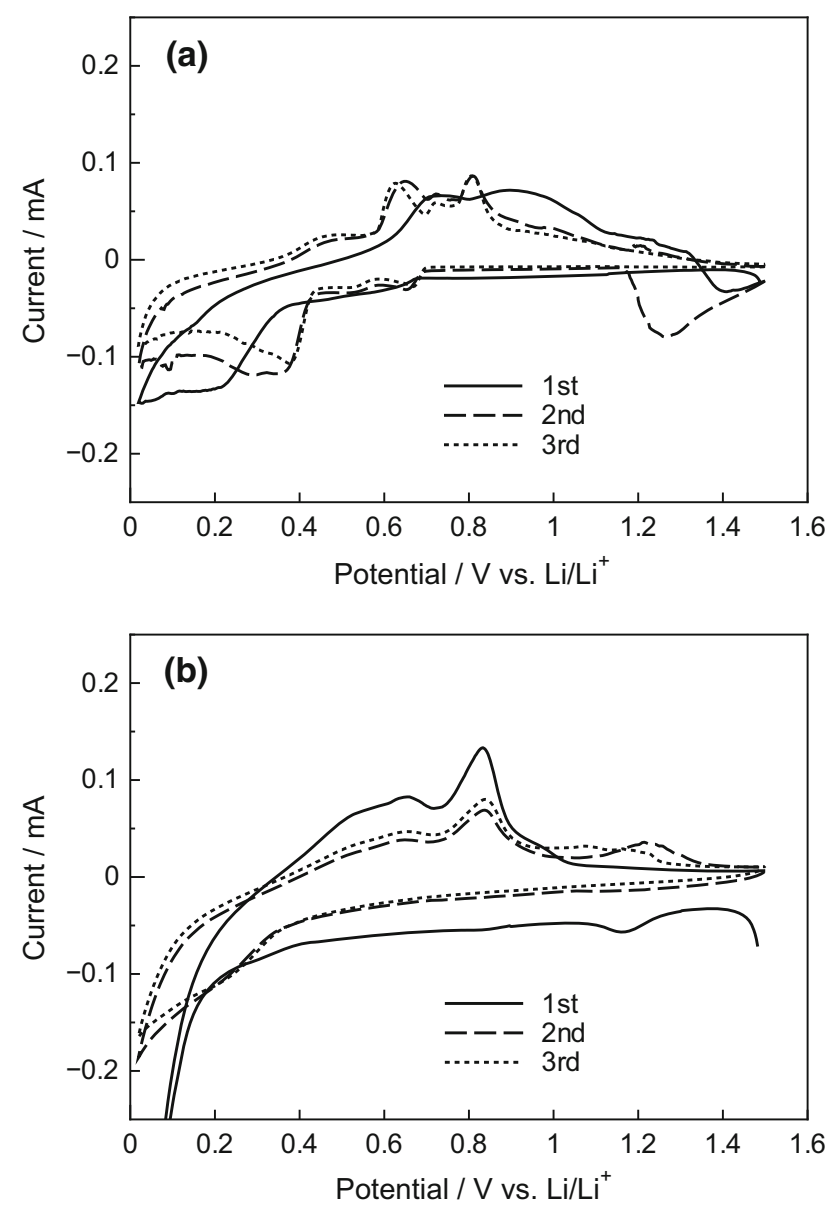

Fig. $5 \mathrm{CVs}$ for $\mathbf{a}$ a tin plating layer on a copper film and $\mathbf{b}$ a tin plating layer on a Cu/MWCNTs composite film (equivalent to the new tin anode structure)
Figure 5a presents the initial three cyclic voltammograms obtained from a tin layer on a copper layer. During the discharge (or lithiation) process in the first cycle, a small shoulder is seen at approximately $0.7 \mathrm{~V}$, followed by a cathodic peak at $0.2 \mathrm{~V}$. In contrast, during charging (or delithiation) in the first cycle, broad anodic peaks are present at 0.7 and $0.85 \mathrm{~V}$, followed by a cathodic peak at $1.4 \mathrm{~V}$. In the case of the second cycle, a cathodic peak at $1.25 \mathrm{~V}$ followed by a small shoulder at $0.7 \mathrm{~V}$ and a large broad cathodic peak at $0.3 \mathrm{~V}$ appear during lithiation, while a small shoulder at approximately $0.4 \mathrm{~V}$ followed by anodic peaks at $0.63,0.72$, and $0.82 \mathrm{~V}$ are seen. The $\mathrm{CV}$ profile generated during the third cycle is almost the same as the second $\mathrm{CV}$ profile except for the cathodic peak at $1.25 \mathrm{~V}$. These profiles are similar to previously reported data for the charge-discharge behaviors of tin active layers fabricated by plating [27, 28] and sputtering [29] on copper substrates. The cathodic peaks more negative than $0.7 \mathrm{~V}$ and the anodic peaks between 0.4 and $0.9 \mathrm{~V}$ are assigned to lithium alloying and dealloying, respectively, while the cathodic peaks at $1.4 \mathrm{~V}$ in the first cycle and at $1.25 \mathrm{~V}$ in the second cycle likely result from solvent decomposition and solid electrolyte interphase (SEI) formation [28]. Figure $5 \mathrm{~b}$ shows the initial three cyclic voltammograms generated by a tin layer on a $\mathrm{Cu} / \mathrm{CNT}$ s composite layer. During the lithiation process of the first cycle, cathodic peaks are seen at 1.15 and $0.02 \mathrm{~V}$. The former peak can most likely be assigned to solvent decomposition and SEI formation and the latter to lithium alloying. The latter lithiation peak obtains a maximum value of $-0.58 \mathrm{~mA}$. On the contrary, during the delithiation process in the first cycle, broad anodic peaks are present at 0.5 and $0.63 \mathrm{~V}$, followed by a sharp anodic peak at $0.82 \mathrm{~V}$, all due to lithium dealloying. $\mathrm{Li}$ et al. have reported that the currents associated with lithiation and delithiation of a Sn/CNTs composite film is greater than those obtained from a tin film in the first $\mathrm{CV}$ cycle, and that CNTs may improve the lithiation and delithiation rates [19]. In the present study, since the lithiation and delithiation currents obtained from the $\mathrm{Sn}$ / CNTs composite layer are larger than those of the tin layer in the first cycle (Fig. 5a, b), the CNTs on or in the tin layer appear to have improved the lithiation and delithiation rates. In the case of the second cycle, a small shoulder appears at approximately $0.35 \mathrm{~V}$, followed by a cathodic peak at $0.02 \mathrm{~V}$ due to lithium alloying during the lithiation process. Conversely, broad anodic peaks at $0.63 \mathrm{~V}$ and a relatively sharp peak at $0.82 \mathrm{~V}$ result from dealloying. The $\mathrm{CV}$ profile for the third cycle is very similar to that for the second cycle.

Figure 6a shows the charge-discharge curves of a tin layer on a copper layer. The first discharge and charge capacities are 442 and $349 \mathrm{mAh} \mathrm{g}^{-1}$, respectively, while the irreversible capacity is $73 \mathrm{mAh} \mathrm{g}^{-1}$. These values are 

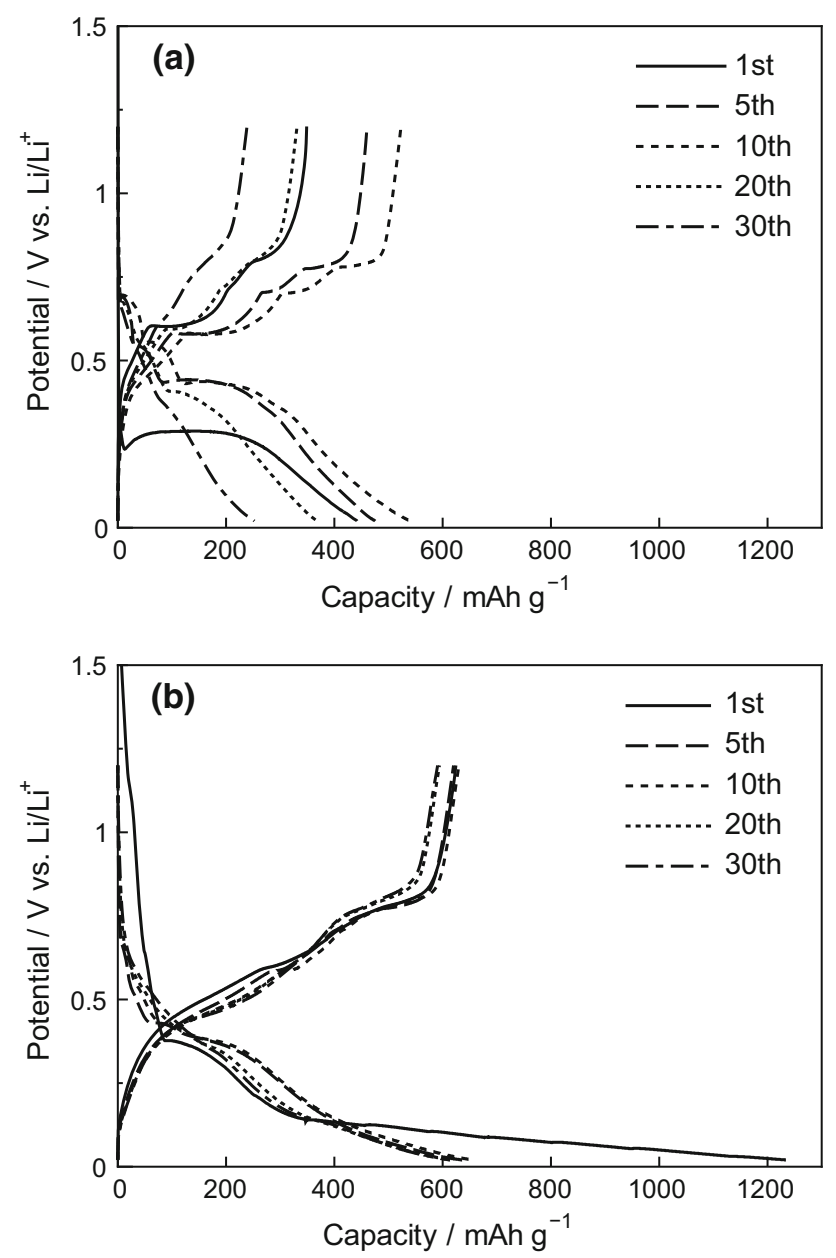

Fig. 6 Charge-discharge plots for a a tin plating layer on a copper film and $\mathbf{b}$ a tin plating layer on a $\mathrm{Cu} / \mathrm{MWCNTs}$ composite film (equivalent to the new tin anode structure)

significantly lower than the theoretical capacity of tin (994 $\mathrm{mAh} \mathrm{g}^{-1}$ ), meaning that lithiation does not proceed perfectly under the conditions employed in this study (including a rate of approximately $0.1 \mathrm{C}$ ). The discharge and charge capacities are observed to increase with increasing cycle numbers and reach maximum values of 540 and $523 \mathrm{mAh} \mathrm{g}^{-1}$ at 10 cycles, respectively. These capacity increases may have been caused by the generation of cracks on the tin active layer during cycling, leading to faster lithiation of the tin layer. After 10 cycles, the discharge and charge capacities decrease with cycle number and reach minimum values of 252 and $239 \mathrm{mAh} \mathrm{g}^{-1}$ at 30 cycles, respectively. These decreases are the result of the pulverization and isolation of the tin layer from the copper layer. In contrast, the charge-discharge curves of a tin layer on a $\mathrm{Cu} / \mathrm{CNTs}$ composite layer are strikingly different (Fig. 6b). The first discharge and charge capacities of the tin layer on the $\mathrm{Cu} / \mathrm{CNTs}$ composite layer were 1234 and $624 \mathrm{mAh} \mathrm{g}^{-1}$, respectively, both of which are remarkably larger than those of the tin layer on the copper layer. The irreversible capacity was $610 \mathrm{mAh} \mathrm{g}^{-1}$, a value that is also much greater than that generated by tin on copper. These results are consistent with the first $\mathrm{CV}$ profiles shown in Fig. 5. That is, the current for the lithiation and delithiation of tin on the $\mathrm{Cu} / \mathrm{CNT}$ s is larger than that of tin on a copper layer. Thus, the presence of CNTs in or on the tin active layer improves the lithiation and delithiation rates in the first cycle. Since the observed discharge capacity (1234 $\mathrm{mAh} \mathrm{g}^{-1}$ ) exceeds the theoretical value for tin $\left(994 \mathrm{mAh} \mathrm{g}^{-1}\right)$, at least a part of the irreversible capacity $\left(610 \mathrm{mAh} \mathrm{g}^{-1}\right)$ is most likely due to solvent decomposition and SEI formation. At the fifth cycle, the discharge and charge capacities are 636 and $620 \mathrm{mAh} \mathrm{g}^{-1}$, respectively, and the irreversible capacity is quite small $\left(16 \mathrm{mAh} \mathrm{g}^{-1}\right)$. Subsequent to five cycles, there is little change in the discharge and charge capacities.

Figure 7 summarizes the cycling performance of a tin layer on copper and a tin layer on a $\mathrm{Cu} / \mathrm{CNT}$ s composite layer. The tin layer on the $\mathrm{Cu} / \mathrm{CNTs}$ composite layer shows remarkably improved cyclability compared to the tin on copper specimen, maintaining a reversible capacity of $591 \mathrm{mAh} \mathrm{g}^{-1}$, a value that is approximately 1.6 times greater than the theoretical capacity of graphite even after 30 cycles, equivalent to a reversible capacity retention of $95 \%$. In contrast, the tin on copper sample has a value of $239 \mathrm{mAh} \mathrm{g}^{-1}$ after 30 cycles, equal to a retention of $68 \%$. The coulombic efficiency of a tin layer on a $\mathrm{Cu} / \mathrm{CNTs}$ composite layer is $91 \%$ after the second cycle and over $95 \%$ after three cycles, while a tin layer on a copper layer shows values of 96,90 , and $94 \%$ following the second, 20th, and 30th cycles, respectively.

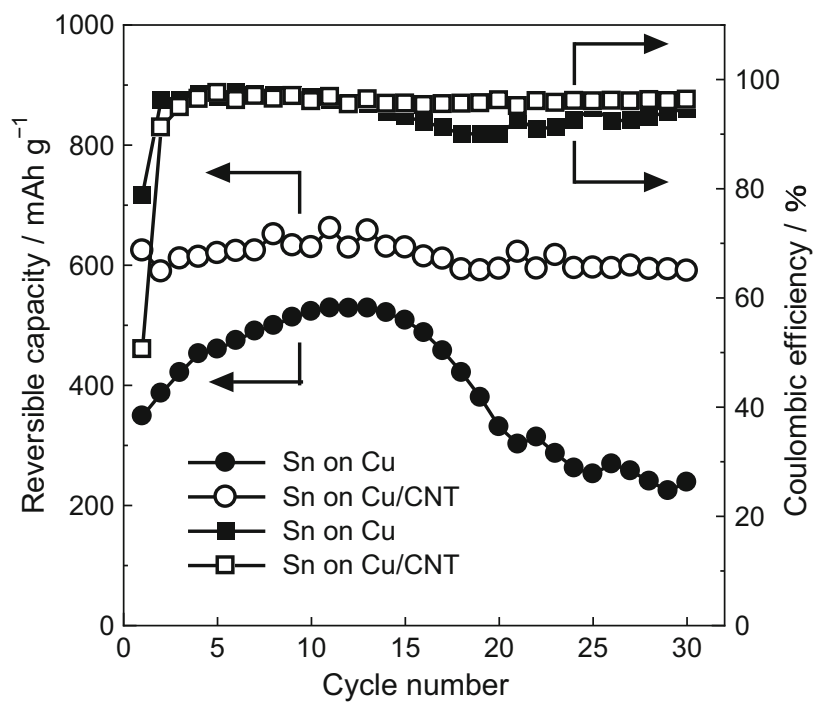

Fig. 7 Cycling performances of a tin plating layer on a copper film and a tin plating layer on a $\mathrm{Cu} / \mathrm{MWCNT}$ composite film (equivalent to the new tin anode structure) 

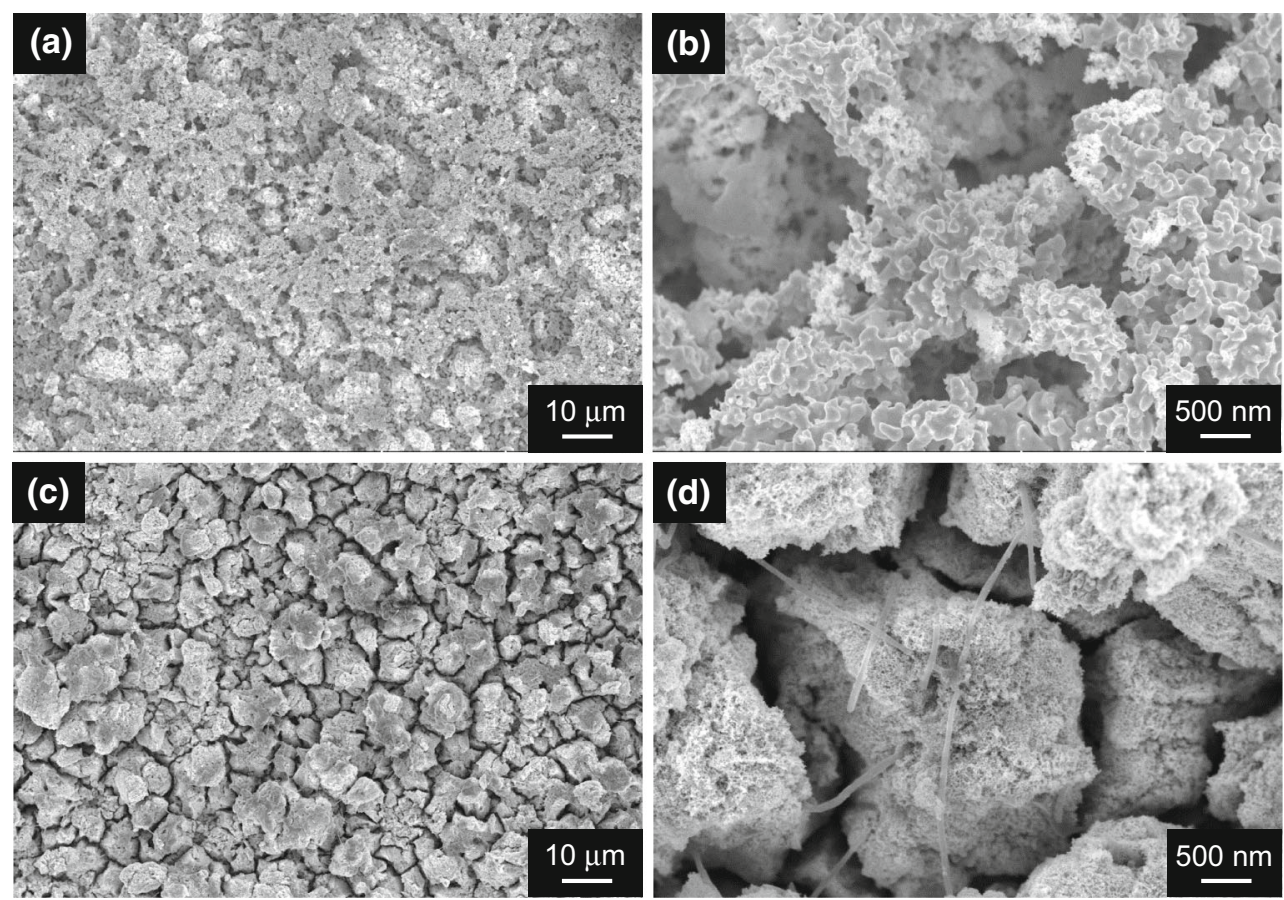

Fig. 8 Surface SEM images of anodes after cycling trials ( 30 cycles): a a tin plating layer on a copper film, $\mathbf{b}$ a high magnification view of (a), c a tin plating layer on a $\mathrm{Cu} / \mathrm{MWCNT}$ composite film (equivalent to the new tin anode structure), and $\mathbf{d}$ a high magnification view of (c)

Figure 8 shows surface SEM images of the anodes after 30 cycles. Figure 8a presents an image of a tin layer on copper, in which obvious shedding of tin is seen on parts of the anode. This shedding is one reason for the drop in capacity evident during the cycling trials. Figure $8 \mathrm{~b}$ shows a higher magnification view of Fig. 8a, where small particles of tin around 200-300 $\mathrm{nm}$ in diameter may be seen. As the diameter of the tin grains was in the range of 3-4 $\mu \mathrm{m}$ prior to cycling (Fig. 3b), pulverization of the tin grains must have resulted from the severe volume changes during the cycling tests. In contrast, although cracks are seen, much of the original tin remains on the surface of the anode (Fig. 8c), accounting for the high capacity even after 30 cycles. Figure $8 d$ shows a higher magnification image of Fig. 8c. In addition to cracks, it is evident that the pulverization of the tin layer has proceeded considerably in this sample. However, the CNTs that are partly fixed in the copper underlayer serve to fasten the tin layer tightly. This fastening effect suppresses shedding of the tin active material from the anode, resulting in superior cyclability.

\section{Conclusions}

A new tin anode structure for lithium-ion batteries, in which CNTs fasten the copper underlayer and tin active material layer, has been fabricated using plating techniques. CV measurements show that the lithiation mechanism of the new tin anode is different from that of a standard tin anode in the first cycle and that the lithiation rate is improved by the presence of CNTs. This novel tin anode exhibits superior cycling performance and maintains a high reversible capacity of $591 \mathrm{mAh} \mathrm{g}^{-1}$ even after 30 cycles. This superior cyclability is attributed to the fastening effect of the CNTs, in which a portion of each CNT is fixed tightly in the copper underlayer.

Acknowledgments This work was supported by a Grant-in Aid for Scientific Research (B) (No. 26289270) from the Japan Society for the Promotion of Science (JSPS).

Open Access This article is distributed under the terms of the Creative Commons Attribution 4.0 International License (http://crea tivecommons.org/licenses/by/4.0/), which permits unrestricted use, distribution, and reproduction in any medium, provided you give appropriate credit to the original author(s) and the source, provide a link to the Creative Commons license, and indicate if changes were made.

\section{References}

1. Winter M, Besenhard JO (1999) Electrochemical lithiation of tin and tin-based intermetallics and composites. Electrochim Acta 45:31-50

2. Tamura N, Ohshita R, Fujimoto M, Fujitani S, Kamino M, Yonezu I (2002) Study on the anode behavior of Sn and Sn-Cu alloy thin-film electrodes. J Power Sources 107:48-55

3. Ui K, Kikuchi S, Kadoma Y, Kumagai N, Ito S (2009) Electrochemical characteristics of $\mathrm{Sn}$ film prepared by pulse 
electrodeposition method as negative electrode for lithium secondary batteries. J Power Sources 189:224-229

4. Kim R, Nam D, Kwon H (2010) Electrochemical performance of a tin electrodeposit with a multi-layered structure for Li-ion batteries. J Power Sources 195:5067-5070

5. Beattie SD, Dahn JR (2003) Single bath, pulsed electrodeposition of copper-tin alloy negative electrodes for lithium-ion batteries. J Electrochem Soc 150:A894-A898

6. Pu W, He X, Ren J, Wan C, Jiang C (2005) Electrodeposition of $\mathrm{Sn}-\mathrm{Cu}$ alloy anodes for lithium batteries. Electrochim Acta 50:4140-4145

7. Finke A, Poizot P, Guery C, Tarascon JM (2005) Characterization and Li reactivity of electrodeposited copper-tin nanoalloys prepared under spontaneous current oscillations. J Electrochem Soc 152:A2364-A2368

8. Mukaibo H, Sumi T, Yokoshima T, Momma T, Osaka T (2003) Electrodeposited Sn-Ni alloy film as a high capacity anode material for lithium-ion secondary batteries. Electrochem SolidState Lett 6:A218-A220

9. Mukaibo H, Momma T, Osaka T (2005) Changes of electrodeposited Sn-Ni alloy thin film for lithium ion battery anodes during charge discharge cycling. J Power Sources 146:457-463

10. Hassoun J, Panero S, Scrosati B (2006) Electrodeposited Ni-Sn intermetallic electrodes for advanced lithium ion batteries. J Power Sources 160:1336-1341

11. Zhao HP, Jiang CY, He XM, Ren JG (2008) A new process of preparing composite microstructure anode for lithium ion batteries. J Power Sources 184:532-537

12. Nishikawa K, Dokko K, Kinoshita K, Woo SW, Kanamura K (2009) Three-dimensionally ordered macroporous Ni-Sn anode for lithium batteries. J Power Sources 189:726-729

13. Hassoun J, Panero S, Simon P, Taberna PL, Scrosati B (2007) High-rate, long-life Ni-Sn nanostructured electrodes for lithiumion batteries. Adv Mater 19:1632-1635

14. Jiang T, Zhang S, Qiu X, Zhu W, Chen L (2007) Preparation and characterization of tin-based three-dimensional cellular anode for lithium ion battery. J Power Sources 166:503-508

15. Zhao X, Xia Z, Xia D (2010) Electrochemical performance of Sn film reinforced by $\mathrm{Cu}$ nanowire. Electrochim Acta 55:6004-6009

16. Shafiei M, Alpas AT (2011) Electrochemical performance of a tin-coated carbon fibre electrode for rechargeable lithium-ion batteries. J Power Sources 196:7771-7778
17. Oberlin A, Endo M, Koyama T (1976) Filamentous growth of carbon through benzene decomposition. J Cryst Growth 32:335-349

18. Iijima S, Ichihashi T (1993) Single-shell carbon nanotubes of 1-nm diameter. Nature 363:603-605

19. Li CM, Zhang RY, Li WS, Zhao LZ, Hu SJ, Rao MM, Xu JX (2007) Ultrasonic-electrodeposited Sn-CNTs composite used as anode material for lithium ion battery. Trans Nonferr Met Soc China 17:s934-s936

20. Zhao X, Xia Z, Xia D (2010) Electrochemical performance of Sn film reinforced by $\mathrm{Cu}$ nanowire. Electrochem Acta 55:6004-6009

21. Arai S, Endo M (2004) Carbon nanofiber-copper composites fabricated by electroplating. Electrochem Solid-State Lett 7:C25C26

22. Arai S, Endo M (2005) Various carbon nanofiber-copper composite films prepared by electrodeposition. Electrochem Commun 7:19-22

23. Arai S, Saito T, Endo M (2010) Effects of additives on $\mathrm{Cu}-$ MWCNT composite plating films. J Electrochem Soc 157:D127D134

24. Arai S, Saito T, Endo M (2010) Cu-MWCNT composite films fabricated by electrodeposition. J Electrochem Soc 157:D147D153

25. Arai S, Kato A (2013) Mechanism for codeposition of multiwalled carbon nanotubes with copper from acid copper sulfate bath. J Electrochem Soc 160:D380-D385

26. Arai S, Suwa Y, Endo M (2011) Cu/multiwalled carbon nanotube composite films fabricated by pulse-reverse electrodeposition. J Electrochem Soc 158:D49-D53

27. Du Z, Zhang S, Jiang T, Bai T (2010) Preparation and characterization of three-dimensional tin thin-film anode with good cycle performance. Electrochim Acta 55:3537-3541

28. Inaba M, Uno T, Tasaka A (2005) Irreversible capacity of electrodeposited Sn thin film anode. J Power Sources 146:473-477

29. Wu M, Li X, Zhou Q, Ming H, Adkins J, Zheng J (2014) Fabrication of $\mathrm{Sn}$ film via magnetron sputtering towards understanding electrochemical behavior in lithium-ion battery application. Electrochim Acta 123:144-150 